\title{
GARGORIS Y HABIS. LA LEYENDA DE LOS ORIGENES DE TARTESOS
}

Fernando GASCÓ*

\section{INTRODUCCION}

Mi intención es tratar ciertos aspectos de un interesante texto recogido en un resumen que hizo un tal Marco Juniano Justino, personaje probablemente del s. III d.C., de una obra de un historiador de época de Augusto y que se llamaba Pompeyo Trogo ${ }^{1}$. El pasaje está en el libro XLIV de la obra, al final de la misma, y nos habla de una serie de reyes que vivieron en "las zonas boscosas de los tartesios en donde se cuenta que los titanes hicieron la guerra contra los dioses".

Entiendo que lo mejor es presentar el pasaje, puesto que su traducción y edición ha presentado algún problema entre los intérpretes:

(*) Profesor Titular de H. ${ }^{a}$ Antigua. Universidad de Sevilla.

1. Los trabajos de conjunto más interesantes y recientes sobre la concepción historiográfica de Pompeyo Trogo son los de O. Seel (Weltgeschichte von den Anfängen bis Augustus im Auszug des Justinus aus Pompeius Trogus, Zurich, 1972; Eine rômische Weltgeschichtc. Studien zum Text der Epitome des Justinus und zur Historik des Pompeius Trogus, Nürnberg, 1972). Abordan dos temas importantes en el autor y estrechamente relacionados con las notieias ofrecidas sobre la Península Ibérica —su punto de vista en torno a los pueblos bárbaros y su presunta disposición antirromana-G.B. Sunseri ("Sul presunto antiromanesimo di Timagene" en Studi di Storia Antica offerti degli allievi a Eugenio Manni, Roma, 1976, pp. 91-101) y E. Malaspina ("Uno storico filobarbaro: Pompeo Trogo", Romanobarbarica, I (1976), pp. 135-158). Véase también la excelente relación bibliográfica incluida en l a traducción de la obra realizada por L. Santi Amantini: Giustino, Storie Filippiche, Milán, 1981. 
"Las zonas boscosas de los tartesios en donde se cuenta que los titanes hicieron la guerra contra los dioses, las habitaron los curetes ${ }^{2}$, cuyo antiquísimo rey Gárgoris descubrió la forma de recoger la miel. Puesto que tuvo un nieto resultado de una deshonra de la que fue objeto su hija ${ }^{3}$, quiso por temor al escándalo eliminar al pequeño por distintos sistemas. Sin embargo, preservado a lo largo de todas sus vicisitudes por una especial fortuna, alcanzó al final el trono por compasión ante tantos peligros como había pasado. Primero de todo, (el abuelo) habiendo ordenado abandonarlo y después de varios días enviando a buscar el cuerpo del expósito, se le halló alimentado por la leche de diversas fieras. Después, conducido de nuevo a casa, mandó arrojarlo a un sendero estrecho por el que solían pasar manadas de animales ${ }^{4}$-crueldad extrema la de quien prefirió que pisoteran al nieto antes que darle simplemente muerte-. Tras haber resultado también allí incólume, sin que le faltara la comida, lo arrojó primero a perros hambrientos y furiosos por varios días de ayuno, y después también a los cerdos. Así las cosas, puesto que no sólo no resultaba dañado, sino que incluso era alimentado por algunas hembras, mandó por último arrojarlo al Océano. Entonces, manifiesta la voluntad divina, fue transportado entre las furiosas aguas y el oleaje, como por una nave y no como por la marea, y fue abandonado en la orilla con suave mecido. No mucho después se acercó una cierva que le ofrecio las ubres al niño. A partir de entonces, por la continua atención de la nodriza, alcanzó el niño una notabilísima ligereza y recorría montes y bosques mezclado con los grupos de ciervos sin quedarse atrás. Por fin capturado por un lazo, fue entregado al rey como regalo. Entonces reconoció al nieto por el parecido y por unas marcas que le habían sido impresas de recién nacido. Sorprendido por sus tantas vicisitudes y peligros, le designó su sucesor. Se le impuso el nombre de Habis. Este, así que recibió el poder, fue tan excelso que no en vano parecía haber sido preservado por el poder divino. Sometió con las leyes al pueblo bárbaro, fue el primero que enseñó a uncir los bueyes al arado y a buscar el alimento en el surco

2. Desde hace ya mucho tiempo se viene aceptando por algunos autores la corrección textual que lee "cunetes" en lugar de "curetes". Véase en calidad de ejemplo lo que ya decía en el siglo pasado Cortés y López en su interesantísimo Diccionario: “...y yaludiendo al mismo concepto Trogo Pompeyo, compendiado por Justino, dice en el lib. 44, que en los hosques y saltos de los Cunetes o Cinetes, escrito por descuido Curetes, allí fue donde los titanes movieron su guerra contra los dioses..." (Diccionario Geográfico-histórico de la España Antigua. Tarraconense, Bética y Lusitania, Madrid, 1835, vol. III, p. 412, s.v. Tartessi Regio). En la actualidad algunos autores mantienen esta corrección. En mi opinión el litus curense de Plinio el Viejo (III 7) nos permite ser conservadores con los manuscritos y mantener a los "curetes" como la lectura idónea, vid. infra.

3. Strupum se debe traducir como "deshonra" y no como "incesto". Ciertos estudiosos, por otra parte bien informados y acertados en el análisis de otras facetas del pasaje, traducen, sin embargo, de manera incorrecta stuprum, cf. J. Caro Baroja, "La «realeza» y los reyes en la España Antigua", en Estudios sobre la España Antigua, Madrid, 1971, p. 104; J. Bermejo, Mitología y mitos de la Hispania Prerromana, Madrid, 1982, p. 65, con n. 12, ahí más referencias.

4. Armenta se traduce mejor en este contexto como "manadas de animales" (salvajes) que "ganados". 
y, por el aborrecimiento de lo que había sufrido en el pasado, forzó a los hombres a dejar sus alimentos salvajes por otros más suaves. Sus aventuras parecerían fabulosas, si la tradición no dijera que los fundadores de Roma fueron alimentados por una loba y Ciro, rey de los persas, por una perra. También fueron prohibidos por él al pueblo ${ }^{5}$ los trabajos serviles y la plebe fue distribuida en siete ciudades. Muerto Habis, el reino fue conservado por muchos siglos por sus sucesores. En otra parte de Hispania que está formada por islas, fue rey Gerión. En ella hay tal abundancia de pasto que, si no se interrumpiera el engorde por el ayuno, el ganado reventaría. Entonces el ganado de Gerión, que por aquel tiempo era la única riqueza, alcanzó tal fama que trajo a Hércules desde Asia movido por la magnitud del botín. Además cuentan que el propio Gerión no era de tres cuerpos, como se dice en la fábula, sino que eran tres hermanos tan bien avenidos que parecían gobernarse por un sólo espíritu, y que no hicieron la guerra a Hércules por su cuenta, sino que viendo que sus ganados eran robados, intentaron recuperar lo perdido con las armas.

Después de estos reinos de Hispania, fueron los cartagineses los primeros en tomar el poder de la provincia". (Justino XLIV 4-5).

El texto tiene unos rasgos muy característicos: por de pronto, no tiene una cronología precisa; los sucesos que se narran se sitúan simplemente antes de la ocupación cartaginesa de la Península Ibérica y además el hecho de que pase a narrar inmediatamente después de la de Habis la historia de Gerión y la venida de Hércules en busca de su ganado, nos hace pensar que no se le atribuía una cronología determinada. Se explica por ello que Luis José Velázquez, historiador del siglo XVIII, situara a Gárgaris en I.034 a.C. y a su nieto Habis en el 1.019 a.C. ${ }^{6}$, es decir, en los tiempos "fabulosos".

Las referencias geográficas son algo más precisas, aunque no dejan de presentar problemas. En el pasaje se mencionan las zonas boscosas de los tartesios donde habitaban los curetes. A la discutida localización de Tarteso se suma, por tanto, la mención de los "curetes", un pueblo mítico especialmente diestro en descubrimientos civilizadores, pero que tradicionalmente era localizado en Creta.

5. La palabra del texto latino es populus, es decir, todo el "conjunto de ciudadanos", Es un término que cuando aparece junto a plebs, como en este caso, significa la totalidad frente a la parte con menos recursos económicos. No hay, por tanto, que traducir o entender populus por "nobles" como hace Caro Baroja (o.c. p. 105). En mi opinión cuando se menciona la prohibición de trabajos serviles para el "populus" se refiere a una disposición que en teoría alcanza a "todo el pueblo", pero que en la práctica afecta sólo a los de menores recursos económicos, quienes sin duda serían los que se verían forzados a realizar "actividades serviles".

6. Anales de la nación española desde el tiempo más remoto hasta la entrada de los Romanos: sacados únicamente de los escritos originales y monumentos contemporáneos, Málaga, 1759, p. 24. 
Hay, sin embargo, en Plinio el Viejo un texto que menciona un litus curense inflexo sinu, que se encontraba enfrente de Gades (III,7). Según A. Tovar el lugar se identifica bien con la costa entre Puerto Real y Rota ${ }^{7}$.

Por otra parte, las vicisitudes por las que se hace pasar al niño Habis, son decididamente fabulosas: se le expone a todo tipo de peligros y de todos ellos sale con bien por intervención divina. El tono es tan legendario que aquellos autores que han intentado rescatar alguna verosimilitud de los sucesos tal cual aparecen en la narración, se han visto obligados a rehacerlos en buena medida. Así lo hizo, por ejemplo, otro importante historiador del siglo XVIII, Juan de Ferreras, quien recompuso los hechos hasta dejarlos en los términos que a él le parecían creíbles:

"La crianza y educación de este Habis me parecen tan fabulosas como aquellas de Rómulo y Remo, y de tantos otros; por ello estoy convencido de que fue criado a escondidas por los montañeses, o por pastores a los que su madre había encargado de su cuidado, y que cuando creció, fue reconocido por su madre, quien encantada de apreciar en él sentimientos de honor y valentía le ayudó a subir al trono tras la muerte de Gárgoris"8.

El texto tiene además unos componentes literarios manifiestos en la tensión dramática que acumula la narración, y en la serie de leyendas de estructura y contenido muy similares de las que por otra parte es conocedor el autor cuando expresa:

"Sus aventuras parecerían fabulosas, si la tradición no dijera que los fundadores de Roma fueron alimentados por una loba y Ciro, rey de los persas, por una perra".

Estos elementos poco realistas del texto han obligado a los intérpretes a no ceñirse a la literalidad de los mismos, sino a considerar el pasaje como alusión, signo o recuerdo sintetizado y fabuloso de sucesos, procesos históricos o creencias. En esto, como en tantas otras cosas, ha habido distintas medidas entre los estudiosos. Recuérdese por poner un ejemplo curioso y extremo, en lo que hace al empleo de la imaginación, lo que pensaba D. Joaquín Costa. El insigne polígrafo del siglo pasado y principios de éste, redujo a una sola las leyendas de Gerión, Terón y Habis para llegar a lo que él llamaba "el mito solar de la Tartéside". Decía en conereto:

"Gárgoris viene a ser el mismo monstruo que con nombres y formas infinitas aparece en pugna con un héroe solar en las mitologías aryas y repite el tipo de Geryon, sea su origen la luna, séanlo las nubes... Podemos concluir, con seguridad, que Abidis es el señor soberano y luminoso, el Dios luciente salido de las

7. Iberische Landeskunde, Baden-Baden, 1974, vol. I, p. 50. Remite este autor a la opinión de Hübner que hacía llegar este "litus" en su extremo más oriental hasta Conil.

8. Sólo he podido consultar la obra en la ed. francesa: Histoire Général d'Espagne, París, 1751, vol. I, p. 6 . 
aguas de la nube, o, más claro, el fuego que brota de la tempestad. Andando los siglos, este personaje se transformó en Persia en Feridum, y en España en Ferdinan González y en Bernaldo del Carpio, según es de ver por los rasgos comunes y el aire de familia que ostentan estas cuatro leyendas... La cierva de Abidis, como la vaca Purmayeh, simboliza las nubes o la luz, el rebaño solar: Abidis es alimentado por la leche de la cierva, esto es, por el agua de la nube; los años que Abidis habita con ella en las selvas, representan el tiempo de sequía, o bien la noche, en que el sol se oculta de los ojos de los mortales, y como que se reproduce en la luna, a quien los ciervos estaban consagrados. El rey Zohak es el mismo Gárgoris, la encarnación de Aji-Dahaca, la serpiente que da muerte a la vaca: el triunfo de Feridun o de Abidis simboliza la libertad de las nubes llovedoras y la salida del sol, la victoria de la luz sobre las tinieblas. La leyenda de Bernaldo, en la cual se ha combinado aquella con la del niño Sol, explica y completa la de Abidis: Bernaldo es el sol joven de la mañana (Horo) vengando al sol caduco de la tarde, que sucumbe diariamente los golpes de la serpiente Apep"9.

Es explicable que esta interpretación no gustara a D. Marcelino Menéndez y Pelayo quien en su Historia de los heterodoxos españoles replicaba diciendo:

"Respecto de la leyenda de Gárgoris y Abidis, no vemos claro, ni mucho menos, que se trate de un mito solar. Tal como lo conocemos por el epítome de Justino, es un relato épico, sumamente parecido a la historia fabulosa de la infancia de Ciro, tal como la cuenta Heródoto en su Clío (107-123), o a la de Rómulo y Remo, narrada por Tito Livio en su primera Década. Otras análogas hay de diversos tiempos y razas, y todo ello parece indicar un fondo mitológico que ha persistido en los cuentos populares; pero no sabemos por qué los perros, lobos, ciervos y jabalíes que salvan a Abidis, han de tenerse por fuerzas solares y no por verdaderos animales, como probablemente lo serían para el poeta turdetano que cantó esta leyenda, donde no puede desconocerse el fondo histórico de la colonización de la Bética"10.

Por de pronto, pues, nos encontramos con un texto difícil, ya lo decía el docto comentario de la edición de Benito de Monfort a La Historia General de España del Padre Juan de Mariana:

"El rey Gárgoris. Justino es el único escritor que da noticias de Gárgoris y Abidis, Reyes de los Curetes eu la comarca de Tarteso; pero como esta noticia sólo se funda en su autoridad, es de dudosa fe, y muchos críticos la descartan por sospechosa. D. Luis Velázquez coloca igualmente los sucesos de ambos monarcas en el tiempo fabuloso, y no permiten otra cosa las aventuras y extraña educación de Abidis"11.

9. Poesía popular española y mitología y literatura celto-hispana, Madrid, 1881, p. 293 s.

10. Historia de los heterodoxos españoles, ed. preparada por D. Enrique Sánchez Reyes, Mađrid, 1965 , $2 .^{a}$, vol. VIII, p. 266.

11. Valencia, 1783, vol. I, p. 48. 
El carácter legendario y fabuloso de lo que se nos cuenta, el hecho de que no se pueda apoyar o matizar el texto o parte de él en otros que nos hablaran de lo mismo, ha provocado un número de interpretaciones dispares muy elevado. Por otra parte, ello no podía ser de otra manera. Un texto en donde los datos tienen un carácter tan alejado de la crónica histórica y en donde los referentes son prácticamente inexistentes, un texto así está condenado a verse adaptado a las metodologías interpretativas de los estudiosos y a las visiones que de Tarteso tienen ${ }^{12}$. Es un texto que por este carácter que tiene la información que facilita, no altera los datos que ofrecen otros textos, sino que más bien se ve alterado.

A pesar de todo ello, sigue siendo un texto que ejerce lo que pudiéramos calificar de irresistible atractivo, como se pone de manifiesto por el hecho de que desde el siglo XVI hasta la actualidad los autores ocupados en el estudio de la $\mathrm{Pe}$ níncula Ibérica en época prerromana no se hayan resistido, prácticamente ninguno, a incluir una traducción o un amplio parafraseo e inevitablemente una interpretación.

\section{LOS ORIGENES DE HABIS}

Voy a intentar despejar primero el tema de los orígenes de Habis. Pues entre las cosas que se nos dicen en el pasaje, no es la única, pero sí es la que confiere un tono más legendario al texto.

Se debe señalar en primer lugar que a pesar de las diferencias existentes entre los distintos intérpretes, las comentadas y las que comentaremos, hay algo en lo que todos, desde Pompeyo Trogo, están de acuerdo: la historia de Gárgoris y Habis tiene abundantes paralelos. Se han mencionado los de Rómulo y Remo y también los de Ciro, — de esta leyenda de Ciro Heródoto decía conocer al menos otras tres versiones (I 95) - , otros estudiosos hace relativamente poco tiempo han agregado a Teseo ${ }^{13}$, en la mente de todos está Moisés que tiene un claro precedente en la leyenda de los orígenes de Sargón de Akkad, se podría añadir el caso del tirano Cípselo en Corinto y si se prosiguiera se podría llegar hasta la cifra de 122 leyendas similares ${ }^{14}$.

12. A modo de ejemplo sugiero que se lean los puntos de vista recientes y en absoluto coincidentes de Caro Baroja, o.c., pp. 51 ss.; J. Maluquer de Motes, Tartessos, Barcelona, 1970, pp. 41 ss.; J.M. Blázquez, Tartessos y los orígenes de la colonización fenicia en Occidente, Madrid, 1975, 2. a , p. 55 ss.; J. Bermejo o.c., pp. 61 ss.

13. Caro Baroja, o.c., p. 106.

14. La cifra la facilita O. Murray en Grecia Antigua, Madrid, 1981, p. 140. 
Quizás el estudio de algunas de sus características pueda darnos alguna pista sobre la de Gárgoris y Habis. Se trata en primer lugar de un tipo de leyenda muy vieja que se aplica por primera vez, que yo sepa, a un personaje histórico: Sargón de Akkad (segunda mitad del III milenio) ${ }^{15}$. También se trata de una leyenda que tuvo un gran éxito y no se circunscribió a una zona determinada. Se difundió primero en el próximo Oriente; después hicieron los griegos uso de ella y de éstos la tomaron los romanos. Otro elemento que me gustaría resaltar es que muchos de los personajes cuyos orígenes se encuentran moldeados por este tipo de leyendas son personajes que realmente existieron, constatados por otros documentos, con cronologías suficientemente precisas y contextos históricos relativamente bien determinados.

Es el caso de Sargón, "rey de las cuatro regiones", como le llamaba la titulatura de la época, fundador de la dinastía de Agadé y de un Imperio que sometió bajo un poder único las independientes y enfrentadas ciudades-templo sumerias $^{16}$. Es también el caso de Moisés a quien la tradición "le consideró como autor del Pentateuco, fundador de la religión de Israel, promulgador de la ley, organizador del Pueblo y del culto, jefe carismático, profeta y sacerdote"17. Personaje - a pesar de lo que se afirmaba por una tendencia investigadora hipercrítica que en la actualidad remite y que intentaba restar historicidad a su figura- sin el cual, según decía R. de Vaux, "se hace inexplicable la religión y la existencia misma de Israel"18. Con Ciro, hijo de Cambises, sucede algo semejante. Se trata nada menos que del fundador del Imperio Persa. Fue él quien unió a los dispersas y belicosas tribus persas, sometió al rey medo y después terminó conquistando y organizando un inmenso imperio ${ }^{19}$.

Con Cípselo, otro de los personajes históricos afectados por esta leyenda, también nos encontramos con un fundador, en este caso de una dinastía, aunque breve, de tiranos de la ciudad de Corinto, interrumpiendo el control que sobre la ciudad ejercía el exclusivo clan aristocrático de los Baquíadas ${ }^{20}$.

Pero incluso en las figuras no históricas con orígenes modelados por estas leyendas se encuentran los rasgos fundacionales que hemos visto en Sargón, Moisés, Ciro y Cípselo. Es el caso de Teseo, el héroe ateniense, y de Rómulo, el legendario fundador de la ciudad de Roma. Estas similitudes, bastante evidentes por otra parte, ya las vio Plutarco y las comentó en sus Vidas Paralelas:

15. Su actividad como conquistador se sitúa a partir del 2370 a.C. Hay sin embargo, algunos problemas de cronología, cf. P. Garelli, El Próximo Oriente Asiático, Barcelona, 1976, 3. a , p. 50, 189 ss.

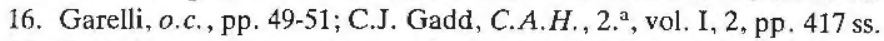

17. R. de Vaux, Historia Antigua de Israel. I. Desde los orígenes a la entrada de Canaan, Madrid, 1975, p. 320.

18. Vaux, o.c., pp. 317-22.

19. Para un desarrollo de la actividad de Ciro se puede consultar la monografía clásica de A.T. Olmstead, History of the Persian Empire, Chicago, 1940, pp. 34-58.

20. J.B. Salmon, Wealthy Corinth. A History of the City to 338 B. C., Oxford, 1984, pp. 186-96. 
“Parecía, en verdad, acomodarse Teseo a Rómulo en muchos puntos de semejanza? Efectivamente, nacidos ambos de un modo ilegítimo y oscuro, gozaron fama de que eran hijos de dioses, «y ambos guerreros, lo que por cierto ya también sabemos todos» (Hom. Il. VII 281) y con la inteligencia asociada a la fuerza. Además, de las ciudades más preclaras, aquél realizó la fusión de Atenas y éste fundó Roma" (Teseo, I 2, 1-2. Trad. Pérez Jiménez).

Se trata, por tanto, de un tipo de leyenda que se introduce en los orígenes de personajes, históricos o no, a los que se les atribuyen importantes tareas innovadoras, sean éstas de adquisición o consolidación de poder, de organización del mismo o de alteración del preexistente. Son por lo general personajes de orígenes dudosos, con antepasados paternos desconocidos o poco nobles, sin una genealogía, sin un poder de la sangre que de por sí justificara la gran tarea acometida con éxito ${ }^{21}$. Por ello mismo necesitan que su misión se asiente en la voluntad divina o en un destino que está por encima de las acciones de los hombres. Todos los reyes y caudillos, antiguos y modernos, lo son "por la gracia de Dios", pero sin duda, la asistencia de los dioses se requiere que sea más efectiva, cuando las empresas y actividades son especialmente arduas 22 .

Nadie hubiera podido suponer que Sargón de Agadé de origen oscuro (era además un semita en un contexto de clara hegemonía sumeria) y humildes comienzos, dejado a su suerte en un cesto y adoptado por un aguador llegara a convertirse en el fundador del primer imperio del Oriente Próximo. Lo cuenta la propia leyenda:

"Sargón, el soberano potente, rey de Agadé, soy yo. Mi madre fue una sacerdotisa; a mi padre no lo conocí. Los hermanos de mi padre amaron las colinas. Mi ciudad es Azupiranu, situada en las orillas del Eúfrades. Mi madre me concibió, en secreto me dio a luz. Me puso en una cesta de juncos, con pez selló mi tapadera. Me lanzó al río, que no se levantó sobre mí. El río me transportó y me llevó a Akki, el aguador. Akki el aguador, me sacó cuando hundía su pozal. Akki el aguador, me aceptó por hijo suyo y me crió. Akki el aguador, me nombró su jardinero, Mientras era jardinero, Ishtar me otorgó (su) amor, y..."23.

Fue la ayuda y favor de la diosa Ishtar y la veneración de Sargón por Marduk ${ }^{24}$ lo que hizo posible el éxito de las distintas empresas realizadas por él.

21. Lo señalaba con acierto R.M. Ogilvie en A Commentary on Livy, Books 1-5 (Oxford, 1970, p. 46), cuando estudiaba los pasajes relativos a los orígenes de Rómulo: "It is an age-old explanation... to account for the emergence of a new force without background or pedigree".

22. Ello es lo que se pone de manifiesto en estos sucesos y no el "carácter divino" de las instituciones que fundan estos personajes, aunque por descontado todo poder ejercido en la Antigüedad tiene un fundamento teocrático.

23. J.B. Pritchard, La sabiduria de Oriente, Barcelona, 1966, p. 100 s.

24. La leyenda de Sargón cuenta como Ur-Zababa, rey de la Cuarta Dinastía de Kish, actuó impíamente con el dios Marduk y la reacción del "devoto" Sargón que de esta manera alcanzó el favor del dios y con él el control del territorio, Gadd, o.c., p. $418 \mathrm{~s}$. 
Tampoco era previsible, que sin la ayuda y favor de Yahveh, Moisés, en país extranjero, pertenenciendo a un pueblo que vivía sometido en Egipto y abandonado a las aguas, también en una cesta, pudiera no sólo sobrevivir, sino llevar a buen término la importante tarea que le había sido encomendada. Pero es sabido que Moisés realizó esto como un mandato expreso de la divinidad que así lo quería y así se lo dijo. Al final del Deuteronomio se describe con gran claridad, tras ser narrada la muerte de Moisés, ese carácter de portavoz y ejecutor de la voluntad divina que tuvo el patriarca:

"No ha vuelto a surgir un profeta como Moisés, a quien Yahvéh trataba cara a cara, ya sea por todas las señales y prodigios que Yahvéh le mandó realizar en el país de Egipto, contra el Faraón, todos sus siervos y todo su país, ya por la mano tan fuerte y el gran temor que empleó Moisés a los ojos de todo Israel". (Dt. XXXIV, 10-12. Trad. Bib. de Jerusalem).

Sucede lo mismo con la leyenda de Ciro. De nada le sirvió al rey medo Astiages casar a su hija Mandane con Cambises, un persa indigno de ella, para evitar que se cumplieran los sueños que le prenunciaban que de ella nacería quien llegaría a conquistar toda Asia. La divinidad protegía a este joven y desde esta óptica narra Heródoto el ascenso de Ciro. Así cuando Harpago le propuso a Ciro revelarse contra Astiages, el rey medo, le dijo según Heródoto:

"Hijo de Cambises, ya que los dioses velan por ti, — pues de otro modo jamás habrías alcanzado tanta fortuna-- debes ahora vengarte de Astiages, tu verdugo. Porque en lo que dependió de su voluntad, muerto estás; si has sobrevivido es gracias a los dioses y a mí..." (Hdt. I 124. Trad. Berenguer).

En el mismo orden de cosas, cuando Ciro arenga a los persas para que se subleven contra los medos, les argumenta diciendo:

"Ahora, por tanto, hacedme caso y seréis libres. Pues yo creo que he nacido, por casualidad providencial para tomar esta empresa en mis manos, y vosotros, considero que no sois hombres inferiores a los medos ni en la guerra ni en otra cosa..." (I 125).

Por fin, cuando Astiages se enteró de la revuelta de Ciro y armó a todos los medos y les puso por general a Harpago, quien no esperaba sino tomar vengaza del rey, lo hizo, según nos cuenta Heródoto "cegado por los dioses" (I 127).

No cabía esperar que de Labda, un miembro menospreciado del clan de los Baquíadas, casada con Eetión por debajo de sus posibilidades a causa de tener un defecto físico, naciera el fundador de un nuevo ordenamiento político en Corinto. Y fue trabajo en balde el realizado por los Baquíadas con objeto de eliminar a Cípselo, una vez que conocieron el oráculo de Delfos en el que se presagiaban las futuras hazañas del que todavía estaba en el seno de su madre y que decía:

"Eetión, nadie te estima, pese a que acreedor de estimación eres. Labda está encinta y parirá un peñasco, que caerá sobre los déspotas y hará justicia en Corinto" (Hdt. V 92 2. Trad. Schrader). 
Era además este oráculo ratificación de otro antiguo que esperaba la llegada de la figura de Cípselo para recibir una justa interpretacián (Hdt. V 92 3). La leyenda insiste además en una serie de "milagrosos azares" que preservan al niño de peligros en otros casos sin duda mortales.

En vano intentó Amulio evitar la maternidad de Rea Silvia consagrándola como virgen vestal y después, una vez madre, privar de la vida a sus hijos. Rómulo, beneficiario de una prodigiosa fortuna que velaba por el origen de Roma, se salvó sorteando todos los peligros. Lo narraba Tito Livio de la siguiente manera:

“Amulio expulsó a su hermano y reinó; y añadiendo un crimen a otro, mató a los descendientes varones de su hermano, y simulando honrar a la hija de Numitor, la consagró vestal, privándola, en la obligaba virginidad, de tener sucesión. Pero, según creo, era preciso que los hados intervinieran en el origen de tan grande y poderosa ciudad y en el principio de un imperio sólo inferior al de los dioses. Violada la vestal Rea Silvia, dio a luz dos hijos, cuya paternidad ella atribuye a Marte, ya por creerlo así, ya porque era más honesto que fuera un dios el autor de la violencia. Mas ni los dioses ni los hombres lograron librar a la madre y a su prole de la crueldad del rey; presa y encadenada la sacerdotisa se ordenó que sus hijos fueran arrojados al río. Desbordado el Tíber, por un evento providencial (quadam divinitus)..." (I 3-4. Trad. J.M. Ruano).

No solamente hay personajes históricos y héroes fundadores relacionados con este tipo de leyendas. Contamos también con leyendas vinculadas con personajes míticos griegos en donde aparecen animales que alimentan a niños abandonados. El caso de los gemelos Neleo y Pelias, hijos de Tiro y Posidón, alimentados respectivamente por una perra y una yegua ${ }^{25}$, o el de Télefo ${ }^{26}$ y Atalanta ${ }^{27}$, criados por una cierva y una osa.

Sin embargo, la leyenda relativa a dioses griegos que yo encuentro con mayores similitudes con estos orígenes conflictivos en estos héroes y en concreto, con el de Habis, aunque sin presentarse en ella el tema de los antepasados dudosos - se trata de dioses-, es la de Zeus ${ }^{28}$. Crono su padre, devorador de sus hijos, es burlado por Rea que le da a comer una piedra en vez del niño y de esta forma consigue salvarle la vida. Pasa Zeus su infancia en Creta, primero alimentado por la cabra Amaltea y después protegido por los curetes. Hay otra versión que recoge Lactancio (div. inst. I 22), según la cual Amaltea y Melisa, hijas del rey Meliseo de Creta, criaron al niño Júpiter con leche de cabra y miel. Como es sabido,

25. Ruiz de Elvira, Mitología Clásica, Madrid, 1982, 2. ${ }^{a}$, p. 266.

26. Ruiz de Elvira, o.c., p. 249.

27. Ruiz de Elvira, o.c., p. 322.

28. Ruiz de Elvira, o.c., pp. $51 \mathrm{ss}$. 
Zeus, una vez adulto y tras la derrota que infringe a su padre en la Titanomaquía, guerra que duró diez años, ocupará el Olimpo a perpetuidad. También con Zeus nos encontramos con un fundador, aunque en este caso lo que se funda es un nuevo orden olímpico.

Son manifiestos los elementos comunes entre la leyenda de Zeus y el texto de Justino. Los curetes protegen a Zeus, también los curetes son los habitantes de las zonas donde gobiernan Gárgoris y Habis; Crono y Gárgoris querían terminar con Zeus y Habis; la cabra Amaltea y una cierva les crían; la miel también aparece rodenado las leyendas de uno y otro, en el caso de Zeus, Melisa le alimenta con miel y en el caso de Habis se dirá que su abuelo Gárgoris fue el descubridor de la apicultura, ello sin contar que Diodoro Sículo atribuye el descubrimiento de la apicultura a los curetes. Es interesante también que se sitúe en Tarteso la Titanomaquí, pues se trata de un episodio vinculado estrechamente a la vida de Zeus y que la tradición situaba en Tesalia (Monte Otris) (Hesiodo, Theog. 632$34)^{29}$.

Es manifiesto que contamos con muchos paralelos, aunque sin duda el punto de referencia más próximo e influyente es el griego.

¿Qué nos aporta el conjunto? Por de pronto hay que decir que este tipo de leyendas, según lo que hemos visto, se puede aplicar, por una parte, a personajes históricos, por otra, a personajes legendarios, que portan en su leyenda noticias reales sobre instituciones y circunstancias por las que pasó el pueblo o ciudad en el que se sitúan —además lo pretenden-, por fin, también a personajes legendarios, pero que no ofrecen otra información histórica que no sea la casual o vinculada con las representaciones-ideas de los que la elaboraron. Pero prescindiendo del grado de información histórica que nos puedan ofrecer, al menos por el momento, en todos los casos que hemos visto nos encontramos con personajes clave, reales o ficticios, pero que trastornan el estado de cosas anterior y fundan otro nuevo. Pienso que se debe retener esto como el mensaje que pretenden ofrecer estas leyendas y también la de los orígenes de Habis. Se le atribuye a Habis en general establecer un nuevo estado de cosas y en particular el fundar, por una parte, un nuevo orden legal, político y social y, por otra, llevar a cabo una tarea civilizadora. No nos puede sorprender que a una figura a cuyas acciones se le concede un carácter innovador tan marcado, se le incorpore una leyenda para sus orígenes como la que conocemos.

$\mathrm{El}$ análisis de los otros particulares que aparecen en la leyenda y que vamos a considerar ahora nos irá ofreciendo otros indicios.

29. Cf. el comentario de M.L. West en Hesiod, Theogony, Oxford, 1978 (=1966), p. 340. 


\section{LOS OTROS RASGOS DE GARGORIS Y HABIS}

Al empezar a tratar estos otros particulares hay que decir que sucede con estas tareas y descubrimientos que se vinculan a Gárgoris y Habis, algo semejante a lo que vimos en la leyenda de los orígenes de este último: la tradición o corpus Iegendario clásico tiene abundantes paralelos.

Empecemos por Gárgoris. El correlato de los "curetes" del texto de Justino, esos habitantes de Tarteso de los que era rey Gárgoris, el descubrir de la apicultura y a los que Habis introdujo en un nuevo estadio de civilización, serían sus homónimos cretenses tal como aparecen en un pasaje de Diodoro Sículo (V 65 , 1-4). También a los habitantes de esta isla griega se les asigna el descubrimiento de la miel, entre otras muchas $\operatorname{cosas}^{30}$. Por esta homonimia Luis José Velázquez pensaba que los curetes cretenses habían llegado al Sur de la Península Ibérica con los fenicios:

"Archaleo, y sus demás Compañeros Fundadores de Gadir, eran Phenices; y como tal los Curetes pudieron acompañarlos en esta transmigración como en todas las otras... Con efecto hay memoria de las cosas de los Curetes en el país inmediato a Gadir; esto es, en los pueblos Tartessios" 31 .

Velázquez también les asignaba la civilización de la zona y por fin concluía diciendo que Gárgoris era curete:

"La invención de la manera de recoger la miel, que Justino atribuye a Gárgoris, dice Diodoro Sículo, que se debió a los Curetes; nueva prueba de que Gárgoris era Curete, según afirma Justino" 32 .

También hay un rey Aristeo, hijo de Apolo y la ninfa Cirene, asociado después con la casa real de Tebas de Beocia, que aprendió de las ninfas además del cultivo de la vid y el apovechamiento de la leche, la apicultura ${ }^{33}$. Sin embargo, por la homonimia y por todas las similitudes comentadas, en especial las existentes entre Zeus y Habis, considero a los curetes cretenses, en los rasgos descritos por Diodoro, como la fuente de inspiración más probable ${ }^{34}$.

En Habis se pueden distinguir dos facetas distintas: una civilizadora y otra de carácter "político". Con respecto a las actividades civilizadoras de Habis encontramos, por de pronto, a una divinidad griega con la que está asociada la difusión de estos elementos entre los hombres. Me refiero a Deméter. Ella fue la que mostró a los hombres la forma de cocinar ciertos productos e introdujo las leyes

30. Se les atribuye la domesticación de animales, el arte de disparar o eon arco y de cazar, la organización de la vida en sociedad, el invento de la espada y el casco...

31. O.c., p. 25.

32. O.c., p. 24.

33. Ruiz de Elvira, o.c., p. 95; Bermejo, o.c., pp. 70 ss.

34. Vid. supra. 
entre los humanos, algo que le valió el apelativo de thesmophoros ${ }^{35}$. Aún más, a su protegido Triptólemo se le asigna por una tradición recogida en diversos autores: la difusión del cultivo de los cereales, la yunta y el arado, cosas todas ellas que había aprendido de Deméter y que a su vez mostró con gran rapidez a los hombres, pues se valió en su periplo docente de un carro tirado por dragones $\operatorname{alados}^{36}$.

También, según cuenta Aristóteles en su Política (1329 b), existió un personaje legendario llamado Italo que hizo que sus súbditos pasaran de la vida pastoril y nomádica a la agrícola y que además cumplió con la tarea de legislador ${ }^{37}$.

Con relación a las actividades "políticas" de Habis hay dos paralelos que considero bastante próximos: Teseo y Rómulo. Ambos son reyes y reyes modélicos, a ambos se les atribuye por la tradición una reorganización del cuerpo de ciudadanos $^{38}$.

\section{GARGORIS Y HABIS: UNA LEYENDA TARTESICA}

Nos encontramos, por tanto, con el hecho de que la tradición legendaria clásica contaba con un repertorio de sucesos de los que algunos presentan una gran similitud con los que aparecen en el pasaje de Justino. Las diferencias existentes entre las leyendas de Gárgoris y Habis y sus paralelos se pueden explicar sin especiales dificultades como fruto de la selección de Justino, que sin duda eliminó detalles del original de Pompeyo Trogo ${ }^{39}$, sin que, a su vez, sepamos el uso que éste hizo de sus fuentes.

Tenemos pues, en el texto de Justino un mosaico legendario cuyas teselas hallan fáciles correspondientes en el acervo legendario clásico. Sin embargo, también se debe señalar que su conjunto es singular ${ }^{40}$.

Pero el importante y debatido tema de las fuentes necesita de una consideración especial $^{41}$. En unas reflexiones en torno a un brillante estudio de G. Dumezil exponía J. Heurgon, cargado de razón, las dificultades para interpretar, como si

35. Ruiz de Elvira, o.c., pp. 69 ss; Bermejo, o.c., p. 82.

36. Ruiz de Elvira, o.c., pp. 70 ss.

37. Caro Baroja, o.c., p. 107.

38. La comparación con estos y otros reyes legendarios y semilegendarios en Caro Baroja, o.c., pp. 109 ss.

39. En el Praefatio Justino nos explica su forma de trabajar: "Resumí todo lo digno de conocimiento omitiendo lo que ni es agradable ni ejemplar. Compuse así un ramillete (florum corpusculum)...".

40. En un pasaje tan reducido hay una exposición legendaria del proceso de civilización de la zona (ateniéndose a ciertas pautas griegas que había sobre el particular, cf. Caro Baroja, o.c., pp. 119 ss.), una narración del nacimiento de un fundador y la exposición de medidas muy heterogéneas atribuidas a él y a su abuelo.

41. Ya mencionaba el tema de las fuentes Menéndez y Pelayo (o.c., vol. VIII, p. 227) y pretendía identificar en ellas a Asclepiades. El tema ha recibido hace pocos años un estudio de manos de L. García Moreno, "Justino 44, 4 y la historia interna de Tartessos", $A E A, 52,(1979)$, pp. 111-130. 
se tratara de las leyendas originales, las elaboradísimas tradiciones relativas a los orígenes de la ciudad de Roma que se podían leer en autores de la época de Augusto $^{42}$. Presentaba J. Heurgon la necesidad de desentrañar los distintos estratos o componentes de las leyendas para ver su cronología y para conocer la razón por la que se incorporaron al núcleo más antiguo. Obviamente el resultado final de una leyenda fruto de sucesivos aportes termina por tener una relación remota con la fase más antigua, tanto por los nuevos elementos que se incorporan, en ocasiones durante muchos siglos, como por el significado y función que desempeña. Los temas, las leyendas adquieren a lo largo de los siglos un nuevo significado en virtud del contexto en el que se emiten y utilizan, y por ello mismo son a su vez sometidos a diversas alteraciones. Lo dicho, por supuesto, no resta interés histórico al estudio de las distintas fases de las leyendas. En época de Augusto, por ejemplo, las leyendas de los orígenes de Roma, que referían sucesos remotísimos, adquirieron una función propagandística manifiesta e intentaron provocar la asociación entre aquella primera fundación y ésta otra patrocinada por $\mathrm{Au}$ gusto tras las Guerras Civiles, por esta razón, por citar un detalle, el Emperador gustaba de ser llamado "Nuevo Rómulo" (Casio Dión LIII 16, 7-8). Pero esta es una consideración que no responde a la pregunta que ha suscitado la reflexión: ¿qué se conserva en estas tradiciones que nos pueda informar de los estadios más primitivos en que fueron elaboradas?

La leyenda de los orígenes de Roma puede venir, de nuevo, en nuestra ayuda. Dicha leyenda tiene dos núcleos iniciales, uno de origen etrusco y otro de origen griego: Rómulo y Remo/Eneas ${ }^{43}$.

En efecto, los antropónimos de Rómulo y Remo nos remiten a un fondo etrusco (rumlna y gens Romilia). En una primera versión parece que no existían los gemelos, sino un solo niño. Hay incluso una estela de Certosa, fechada en el s. IV a.C., en donde aparece una loba amamantando a un humano. No obstante, en el s. III a.C. la tradición sobre los gemelos ya estaba perfectamente establecida. También en el s. III a.C., en torno al 225 a.C., en una dedicación oficial de Roma en Quíos se manifiesta la creencia de que la leyenda de Rómulo y Remo cra la más antigua y difundida. Estos son los elementos más antiguos de la tradición que los historiadores y literatos en general elaboraron y alteraron siguiendo pautas historiográficas, literarias y propagandísticas ${ }^{44}$.

El caso de Eneas es otro. Según la Ilíada (XX 215-240), Eneas sobrevivió a la caida de Troya. Con este expediente inicial los griegos le hacen viajar lejos por el Mediterráneo. Así a finales del s. VI a.C. Eneas ya ocupaba en Roma la posición de héroe fundador como lo prueban tanto fuentes historiográficas del s. V

42. Roma y el Mediterráneo Occidental hasta las Guerras Púnicas, Barcelona, 1971, pp. $150 \mathrm{ss.}$

43. Un tratamiento reciente del tema pueda encontrarse en T.J. Cornell, Procedings of the Cambridge Philological Society, 21 (1975), pp. 1-32.

44. Ogilvie, o.c., pp. 32-3, 46-7. 
a.C. (Helánico, FGH, 4 F 845 = Dionisio de Halicarnaso, I 47-48, 1, fechado en torno al 450 a.C.), como múltiples hallazgos arqueológicos de finales del VI y principios del $\mathrm{V}$ que ponen de manifiesto la difusión del tema de Eneas llevando a cuestas a su padre Anquises en Etruria (Veye y Vulci). El carácter etrusco de la Roma de la época, el hecho de que los latinos, eI otro aporte contemporáneo fundamental en Roma, ya contaran con un fundador (Latino, mencionado en Hesíodo, Theog., 1011-16, se trata de una interpolación fechada a finales del VI a.C.) y la posterior referencia en Helánico nos permite suponer que la leyenda de Eneas como fundador ya estaba fijada a finales del VI o a lo sumo, a comienzos del V a.C. ${ }^{45}$.

Ambas leyendas, como ya es sabido, se funden y así en algunas versiones se convierte a Rómulo en hijo de Eneas (Festo, 326 L) o eu su nieto (Dionisio de Halicarnaso, I 72; Servio, ad Aen. I 273; VI 777).

Pues bien, lo que se cuenta, por una parte, de Gárgoris y Habis, y por otra, de Gerión recuerda a las dos leyendas fundacionales de Roma. Primero contamos con una leyenda indígena - con antropónimos no griegos ${ }^{46}$ y con personajes que no aparecen como tales en la tradición legendaria griega, igual que sucede con Rómulo y Remo-, después también tenemos una leyenda griega; a Gerión no se le sitúa en Hesíodo ( $c a .650$ a.C.) en un lugar concreto, pero en el s. VI a.C. Estesícoro lo localiza en Tarteso en un proceso semejante al que sigue Eneas ${ }^{47}$.

Hecha esta observación inicial basada en un parangón bastante obvio, los problemas que después surgen para reconstruir la cronología de los distintos elementos que configuran la tradición, tal como nos ha llegado, son a mi modo de ver insalvables en la actualidad, como probablemente hubiera sucedido con Roma de no haber ocupado la posición histórica que detendó. ¿Cómo, cuándo y por medio de quién llegó Gerión a la Península Ibérica? ¿Cuándo y cómo se asocia con la leyenda de los orígenes de Tarteso? ¿En qué momento surge la leyenda del héroe fundador? ¿Recibió como Eneas algún tipo de culto ${ }^{48}{ }_{i}$ Cuándo aparecen los elementos literarios y legendarios que le dan buena parte de su forma? ${ }^{49}$

45. R.M. Ogilvie, Roma Antigua y los Etruscos, Madrid, 1981, pp. 34 ss. con un breve pero excelente estado de la cuestión.

46. Cf. M.L. Albertos, La onomástica personal primitiva de Hispania Tarraconense y Bética, Salamanca, 1966. Para Habis simplemente recoge la noticia de Justino (p. 121 y 276), para Gárgoris señala la posibilidad de un radical indoeuropeo al que se añade un sufijo -rix ("rey"), aunque también indica la posibilidad de que no se trate de un nombre indoeuropeo, sino de un radical reduplicado del tipo Bilbilis, Cu.r.u.cu.r.u.a.din, ... (p. 118).

47. A. Schulten, Tartessos, Madrid, 1984 (=1945), p. 104 ss.

48. Es una pregunta importante porque el culto de Eneas cumplía una función unificadora y política y la comparación nos podía permitir presumir algo semejante para Tarteso.

49. Se ha estudiado recientemente la óptica historiográfica de Pompeyo Trogo que mira a los pueblos bárbaros desde un punto de vista moralizante y como una fuente potencial de poder en una hipotética traslatio imperii, cf. O. Seel, Weltgeschichte von den Anfängen bis Augustus im Auszug des Justin aus Pompeius Trogus, Zurich, 1972, sobre los pasajes relativos a la Península Ibérica esp. las pp. 559-60; E. Malaspina, "Uno storico filobarbaro: Pompeio Trogo", Romanobarbarica, 1 (1976), pp. 134-157, esp. 146-9. 
¿Cuánto se "internacionaliza" Tarteso incluyendo en su territorio acaeceres de la mitología griega $?^{50} \mathrm{Y}$ las ideas antropológicas que se dicen existen insertas en la leyenda, ¿cuándo y por qué se incorporan ${ }^{51}$ ¿En qué momento se pueden situar las medidas de carácter social atribuidas a Habis que, como veremos, tienen todos los visos de ser históricas? ¿En dónde está el contexto arqueológico e histórico en el que podemos situar todos estos elementos?

Las preguntas similares que, aunque con ciertas incertidumbres, se pueden responder para Roma, quedan sin contestación en el caso de Tarteso, pues carece del soporte historiográfico, literario y arqueológico que tenemos para Roma que no en vano ocupó una posición hegemónica durante muchos siglos en el Mediterráneo.

\section{LA HISTORICIDAD DE ALGUNA DE LAS MEDIDAS}

Otro elemento digno de estudio y que en parte nos viene sugerido por las comparaciones que hemos venido haciendo, es el de la historicidad de las medidas atribuidas a Habis.

A mí no me cabe la menor duda de que Teseo y Rómulo son personajes legendarios. Forman parte de esos héroes fundadores en torno a los cuales se agrupan por la tradición medidas de toda índole, en algún caso estas medidas son tan numerosas y tan importantes que hubieran resultado excesivas incluso para varias generaciones y no me refiero sólo a los descubrimientos civilizadores. Pero al mismo tiempo, se debe decir que si estas medidas o procesos no se pueden asignar a la voluntad de una persona y menos a una persona legendaria, no por ello dejaron de tener lugar esas medidas y procesos. En otras palabras, si la atribución a tal o cual personaje es falsa, aquello que se les atribuye no lo es.

El caso de Teseo nos puede resultar ilustrativo. Entre otras cosas se dice de Teseo que fueron obras suyas la unificación política y administrativa del Atica, el llamado sinecismo. Se le atribuye de igual manera una transformación de la realeza, en palabras de Aristóteles "fue el primero que se inclinó al pueblo" ( $A . P$. fr. 4. Trad. A. Tovar). Ambas cosas, en efecto, sucedieron en el Atica antes de que comencemos a tener una información histórica clara, por más que se atribuyan a un personaje legendario a quien incluso se le hace compartir algunas correrías con Hércules ${ }^{52}$.

50. Véase lo que al respecto dice L. García Iglesias en "La Península Ibérica y las tradiciones griegas de tipo mítico", $A E A, 52$ (1979), pp. 131-140.

51. Caro Baroja, o.c., pp. $106 \mathrm{ss}$. menciona a Dicearco como una fuente para un sistema de evolución cultural (recolector-agrícola-pastoril) como el que aparece en el texto. Sobre Dicearco cf. Caro Baroja, La aurora del pensamiento antropológico, Madrid, 1983, pp. 125 ss.

52. Su campaña contra las Amazonas, cf. Ruiz de Elvira, o.c., p. 375. 
Sabemos, por ejemplo, que Eleusis y la Tetrápolis de Maratón fueron las últimas zonas en incorporarse en ese proceso unificador que se llama sinecismo ${ }^{53}$. Conocemos también que la transformación de la realeza tuvo lugar y que efectivamente se hubo de hacer con un cierto grado de consentimiento por parte de los reyes afectados, como lo prueba el hecho de que se mantengan en época histórica instituciones en las que se menciona al rey ${ }^{54}$. El caso de Teseo, desde luego, no es exclusivo. También se debe añadir otra consideración y es que las atribuciones no se hicieron de una sola vez, sino que se fueron incorporando al personaje en la misma medida que su figura legendaria quedaba alterada por la utilización que se hiciera de la misma. Pero en cualquier caso, lo que se le atribuye comenzó a ponerse en práctica alguna vez.

Con esta perspectiva podemos pasar al análisis de las medidas asignadas por la tradición a Habis y que son dos:

\section{- La supresión del trabajo servil para el pueblo (populus). \\ - La distribución de la plebe (plebs) en siete ciudades (urbes).}

El primer detalle que posee algún interés histórico es la consignación de una diferenciación social en el pasaje. Cuando en latín populus aparece con plebs la oposición que se establece es entre "todos los ciudadanos" y el "grupo social de menores recursos económicos". Sin embargo, una distribución social tan sencilla aporta poca información. Otra cosa hubiera sido que se nos hubiera informado de su origen, que se nos hubiera dicho que estaba basada en una diversidad étnica o en ciertas actividades económicas.

Distinto grado de sugerencia tiene el tema de la supresión del trabajo servil para el populus. El paralelo más próximo que tenemos es el de Atenas a principios del s. VI a.C., cuando Solón intentaba mediar entre las partes enfrentadas de la ciudad. Decía Solón en una de sus composiciones:

"Y a los que aquí mismo en esclavitud fea estaban, temerosos del carácter de sus dueños libres los hice. Esto por la fuerza de la ley (igualdad), combinando violencia y justicia lo hice, y obré cómo había prometido. Leyes lo mismo para cl malo que para el bueno ajustando para cada uno la recta justicia escribí" (Aristóteles, A.P., XII 4. Trad. A. Tovar).

53. Este proceso se culminaría en torno al año 700 a.C. Sin embargo, hay autores que piensan también en un sinecismo en época micénica, aunque ello es un tema más que dudoso. Las referencias en P.J. Rhodes, A Commentary on the Aristotelian "Athenaion Politeia", Oxford, 1981, p. 76.

54. EI hecho, por ejemplo, dc que exista un magistrado con el título de "Arconte Rey" en Atenas lo prueba. En Roma, cuya monarquía terminó de forma violenta a finales del VI a.C. - la fecha es discutida-, se eliminan de forma drástica todas las referencias que pudieran remitir al rey o a su institución, cf. C. Hignett. A History of the Athenian Constitution to the End of the Fifth Century B.C. Oxford, 1970 (=1952), pp. 38 ss. 
Si la comparación es buena y la medida en efecto se llevó a cabo en Tarteso, como nos dice el pasaje, ello puede remitirnos a un contexto de conflicto social como el que en Atenas provocó el arbitraje y la acción legislativa de Solón. En cualquier caso, si no se consideraran parangonables la Atenas de Solón y Tarteso en alguno de sus momentos, no por ello habría que desechar la idea del conflicto social apuntado en la medida de la supresión de la esclavitud para el pueblo.

Una medida semejante sólo se explica desde una situación reivindicativa. Es por tanto probable que la medida de distribución de la plebe en siete urbes, signifique lo que signifique, estuviera en relación con ese conflicto social. Así lo considero por el hecho de que se precise la adscripción social de los distribuidos en urbes y por ser la plebe la que sin duda había sido afectada por la medida de la supresión de las actividades serviles en el conjunto de ciudadanos (populus).

\section{LA POSIBLE FUNCION DE ESTA LEYENDA}

Las comparaciones que hemos venido haciendo nos muestran que estamos ante una tradición tartésica con paralelos en Grecia y Roma, por ello mismo deberían ponerse en parangón no sólo los personajes que aparecen en unas y otras leyendas fundacionales (Habis, con Teseo y Rómulo...), sino también las funciones que cumplían las susodichas leyendas. Estas leyendas terminaron constituyendo un punto de referencia, un símbolo que sabemos que tenía una labor unificadora y consolidadora en los pueblos y ciudades. Ello es manifiesto con Teseo en Atenas y con Rómulo en Roma. Precisamente por esta función que cumplían se trataba de leyendas de gran vitalidad que se transformaron recibiendo agregados a lo largo de los tiempos.

Por ejemplo, Teseo en la Vida que escribió Plutarco es comparado sistemáticamente con Hércules, bienhechor de la humanidad por sus esforzados trabajos. Pues bien, esta comparación surge a finales del s. VI, se afianza en el V y termina por perfirlarse durante el s. IV a.C., adaptándose en todas las épocas a diversas intencionalidades ${ }^{55}$.

Con Rómulo sucede otro tanto. Su leyenda es muy antigua, pero fue recibiendo sucesivos aportes a lo largo de los tiempos al adaptarse al modelo mitológico griego, al cumplir una función propagandística en las guerras samníticas y contra Pirro en el s. III a.C., o al insertarse en un modelo historiográfico cíclico o que deseaba hacer encajar los rasgos de un personaje con una figura tipo (Rómulo sería el guerrero fundador, Numa el sacerdote-legisador... hasta llegar a Tarquino el Soberbio, el cruel tirano) ${ }^{56}$.

55. Las referencias pueden encontrarse en las notas de A. Pérez Jiménez a Plutarco, Vidas Paralelas, $I$. Teseo-Rómulo-Licurgo-Numa, Madrid, 1985, esp. en p. 161.

56. Ogilvie, o.c., pp. 46 ss. 
La de Gárgoris y Habis tiene todos los rasgos para ser la leyenda fundacional de Tarteso. Tendría esta leyenda esa función unificadora y de punto de referencia que hemos hallado en otras semejantes. Precisamente por ese carácter cargado de significado que hubo de tener la leyenda, se acumularon en ella distintos estratos y al héroe Habis se le atribuyen medidas y rasgos tan heterogéneos, que pueden responder a las distintas fases de la vida de la leyenda.

Sin duda, entre las actividades que se atribuyen a Habis las que ofrecen un grado de mayor información histórica son las que nos hablan de la supresión de las actividades serviles del pueblo y la distribución de la plebe en siete ciudades. Son medidas que es probable que nos estén informando, aunque de forma poco explícita, de un momento en el que hubo de existir algún conflicto social importante en Tarteso.

Voy a terminar citando un texto de Velázquez, el historiador del s. XVIII que he mencionado en varias ocasiones durante el trabajo:

"En fin los Curetes enseñaron a los Españoles la Religión, la Policía, y el gobernarse por leyes, el uso de los metales, la manera de forjar armas, el modo de eombatir, la Philosophía, la Astronomía, la Danza, la Música y la Poesía; las letras, y la manera de escribir, el uso de la moneda, y la manera de acuñarla; y generalmente los primeros rudimentos de las Artes Liberales y mecánicas. Así vemos, que los españoles conservaron después de mucho tiempo las más señaladas costumbres de los Curetes, y singularmente la de danzar armados al son de los golpes concertados de las espadas en los escudos; costumbre, que en los españoles antiguos nota Silio Itálico"s7.

No es verdad todo lo que se les atribuye por Velázquez, pero se convendrá que un pueblo capaz de elaborar y vivir con leyendas tan hermosas como las de Gárgoris y Habis, hubo sin duda de ser un pueblo singular.

57. O.c., pp. $23 \mathrm{ss}$. 